\title{
PERBANDINGAN MODEL PEMBELAJARAN RECIPROCAL TEACHING DENGAN BAMBOO DANCING BERBASIS COOPERATIF LEARNING
}

\author{
Roikhatul Machbubah \\ Mahasiswa Program Studi Pendidikan Agama Islam Fakultas Agama Islam \\ Universitas KH. A. Wahab Hasbullah Tambakberas Jombang. \\ Khoirun Nisa' \\ Dosen Program Studi Pendidikan Agama Islam Fakultas Agama Islam \\ Universitas KH. A. Wahab Hasbullah Tambakberas Jombang. \\ neesaal-khoirot23@gmail.com
}

\begin{abstract}
This study aims to determine the comparison between Reciprocal Teaching learning models and Bamboo Dancing to find out which learning models are effectively used. The difference between Reciprocal Teaching and Bamboo Dancing learning models lies in the way the teaching and learning process is delivered. Reciprocal Teaching Model prioritizes language style or speaking style of students in delivering the material presented, while the Bamboo Dancing learning model prioritizes the activeness of a student in channeling what he gets then they exchange ideas with other friends.

Keyword : Reciprocal Teaching Learning Model, Bamboo Dancing Learning Model, Student Learning Outcomes.
\end{abstract}

\section{A. PENDAHULUAN}

Pendidikan adalah kebutuhan dasar untuk menjalani sebuah kehidupan. Tanpa adanya pendidikan manusia tidak bisa hidup secara sistematis. Dalam realitas hidup menunjukkan suatu proses sebuah pembelajaran. Pendidikan merupakan pilar utama yang menentukan perubahan sosial. Perubahan kearah kemajuan dan kesejahteraan hidup yang lebih berkualitas. Dalam UU sistem pendidikan nasional tahun 2003 disebutkan bahwa : " Pendidikan adalah usaha sadar dan terencana untuk mewujudkan suasana belajar dan proses pembelajaran agar peserta didik secara aktif dapat mengembangkan potensi dirinya untuk memiliki kekuatan spritual, keagamaan, pengendalian diri, kepribadian, kecenderungan, kecerdasan, akhlak 


\section{Roikhatul Machbubah, Khoirun Nisa'}

mulia, serta ketrampilan yang diperuntukkan dirinya, masyarakat, bangsa, dan negara.”.

Salah satu komponen dari sistem pendidikan adalah proses belajar mengajar. Mengajar bagi seorang guru bukanlah sekedar menyampaikan pengetahuan kepada siswa melainkan guru dapat memotivasi siswa agar suasana pembelajaran tetap menyenangkan. Hal ini akan berhasil apabila antar guru dan siswa dapat bekerja sama.

Dalam proses pendidikan di sekolah proses pembelajaran merupakan suatu kegiatan yang berlangsung di dalam kelas atau ruangan. Namun kenyataannya, pelaksanaan pembelajaran masih banyak yang berorietasi pada upaya bagaimana semua materi bisa tersampaikan secara menyeluruh pada siswa, sehingga kurang memberdayakan pengulangan kembali mengenai materi yang diajarkan. Dampaknya, informasi yang diterima tidak bertahan lama dalam memori jangka panjang (long term memory) sehingga daya siswa kurang optimal. Model pendidikan tersebut jika masih dipergunakan maka dampaknya akan menghambat keberhasilan belajar siswa.

Pembelajaran yang aktif dan interaktif adalah hal yang ingin dicapai dalam proses pembelajaran. Hal ini guru adalah fasilitator dalam proses pembelajaran. Sehingga dapat terjalin komunikasi yang efektif antara guru dan siswa. Dalam suasana pembelajaran yang menyenangkan siswa tidak akan merasa terbebani secara perorangan dalam memecahkan masalah yang dihadapi dalam pembelajaran. Dalam pembelajaran yang aktif dan menyenangkan diharapkan akan tumbuh dan berkembang potensi siswa. Sehingga, pada akhirnya dapat mengoptimalisasikan hasil belajar siswa.

Mata pelajaran Sejarah Kebudayaan Islam (SKI) adalah salah satu mata pelajaran yang di ajarkan di MA Rahmat Sa'id Bongkot. Mata pelajaran Sejarah Kebudayaan Islam (SKI)

\footnotetext{
${ }^{1}$ Undang-Undang No.20 Th. 2003 tentangSistemPendidikanNasional, (Jakarta : Sinar Grafika, 2009), hal. 3.
} 


\section{Perbandingan Model Pembelajaran Reciprocal Teaching Dengan Bamboo Dancing \\ Berbasis Cooperatif Learning}

merupakan salah satu pelajaran penting sebagai upaya untuk membentuk karakter dan kepribadian umat. Sejarah Kebudayaan Islam (SKI) adalah sekumpulan peristiwa penting dari tokoh-tokoh muslim dari belahan dunia. Dengan mempelajari Sejarah Kebudayaan Islam (SKI) siswa dapat memperoleh pelajaran yang berharga dari perjalanan dari seseorang tokoh atau generasi zaman dulu.

Siswa juga dapat memperoleh berbagai pelajaran dari proses pembelajaran Sejarah Kebudayaan Islam (SKI) yang di lakukan. Keteladanan dari para tokoh-tokoh muslim sejarah inilah yang ingin di transformasikan kepada generasi muda. Berawal dari kurang berminatnya siswa terhadap mata pelajaran Sejarah Kebudayaan Islam dapat mempengaruhi hasil belajar yang diperoleh.

Hasil wawancara dan observasi awal di MA Rahmat Sa’id Bongkot kegiatan belajar sebagaian peserta didik masih sering berbicara sendiri dengan teman sebangkunya saat kegiatan proses belajar mengajar berlangsung sehingga dapat mengganggu para peserta didik lainnya. Selain itu, setiap pendidik mengajukan pertanyaan dijawab secara serempak, hal ini menunjukkan tidak adanya kepercayaan diri pada peserta didik untuk mengungkapkan pendapatnya. Model pembelajaran yang digunakan yaitu ceramah dan diskusi. Metode ceramah sebagian besar dari peserta didik merasa bosan, sedangkan diskusi sebagian kecil saja yang aktif selebihnya hanya ikut-ikutan saja sebagai pelengkap. Dan salah satu permasalahan umum yang dihadapi siswa adalah sulitnya memahami materi yang disampaikan . Karena materi pelajaran yang mereka pelajari adalah ilmu sejarah maka kegiatan pembelajaran dikelas harus aktif dan bervariatif karena umumnya hanya berisikan cerita-cerita. ${ }^{2}$

Melihat keadaan tersebut maka penulis ingin memberikan salah satu alternatif untuk

\footnotetext{
${ }^{2}$ Hasil wawancara di MA Rahmat Said. Selasa, 5 Agustus 2019
} 


\section{Roikhatul Machbubah, Khoirun Nisa'}

pengajaran tersebut adalah menggunakan model pembelajaran kooperatif. Dimana agar proses pembelajaran yang berlangsung dikelas akan memaksimalkan peserta didik agar lebih aktif dalam proses pembelajaran Penerapan metode pembelajaran yang bervariasi akan mengatasi kejenuhan siswa dalam menyerap sebuah materi yang diajarkan.

Pengalaman belajar secara kooperatif akan menghasilkan keyakinan yang lebih kuat bahwa seseorang merasa disukai, diterima oleh peserta didik lain, dan menaruh perhatian tentang bagaimana kawannya belajar dan adanya keinginan untuk membantu temanya belajar.

Model pembelajaran terdiri dari banyak model, model pembelajaran kooperatif yang baik dan terpilih untuk di terapkan oleh peniliti di sekolah MA Rahmat Said Bongkot ada dua macam yaitu Reciprocal Teaching dan Bamboo Dancing. Beberapa penyebab yang melatar belakangi peniliti sehingga memilih metode tersebut adalah karena ke dua metode tersebut sama-sama memfokuskan keaktifan peserta didik dikelas daripada model pembelajaran yanbg sebelumnya. Selain itu kedua metode tersebut juga lebih mudah dan sederhana dipahami oleh peserta didik kelas berapa saja, dalam menyajikan suatu materi yang membutuhkan kesediaan peserta didik untuk lebih aktif dalam memahamai pelajaran yang diajarkan di dalam kelas. Kedua, pembelajaran tersebut juga memberikan kesempatan kepada peserta didik untuk berkreatifitas dan bertanya jawab kepada teman yang lainnya, sehingga kejenuhan dalam belajar menjadi lebih menyenangkan.

Adapun juga pemilihan metode Reciprocal Teaching dan Bamboo Dancing guna untuk mengetahui model pembelajaran mana yang lebih efektif untuk di pergunakan dan untuk mengarahkan atensi peserta didik terhadap materi yang di pelajari, serta untuk mengajak siswa agar belajar secara aktif. Kedua metode tersebut diharapkan dapat sebagai sarana untuk meningkatkan keaktifan dan kemampuan bernalar siswa. Sehingga, lebih memudahkan peserta 


\section{Perbandingan Model Pembelajaran Reciprocal Teaching Dengan Bamboo Dancing Berbasis Cooperatif Learning}

didik untuk berbagi dan mengolah informasi.

Pembelajaran kooperatif Bamboo Dancing sangat baik digunakan dalam proses pembelajarn SKI di kelas. Selain membuat peserta didik menjadi aktif, penggunaan model pembelajaran ini mengajarkan peserta didik untuk dapat bekerja sama dengan peserta didik lainnya di kelas. Sehingga penerapan pemebelajaran kooperatif Bamboo Dancing dapat membantu dan menghidupkan suasana kelas.

Penerapan pembelajaran kooperatif Reciprocal Teaching pada peserta didik kelas XI MA Rahmat Said Bongkot, juga menjadi pilihan bagi peneliti, karena tujuan metode ini adalah untuk mengasah kemampuan berbicara setiap peserta didik untuk ndapat tampil menjelaskan pelajaran yang diperolehnya kepada teman-temannya.

Pemilihan lokasi sekolah di MA Rahmad Sai'd karena sekolah tersebut merupakan lembaga tertinggi yang menaungi di Yayasan Rahmad Sa'id. Pemilihan itu juga karena lokasi yang cukup dekat dengan peniliti agar memudahkan atau efisien untuk melakukan sebuah penelitian.

Berdasarkan uraian diatas peniliti tertarik untuk melakukan penelitian tindakan kelas yang berjudul " Studi Komparatif Model Pembelajaran Reciprocal Teaching dengan Bamboo Dancing Pada Hasil Belajar Siswa Mata Pelajaran Sejarah Kebudayaan Islam Kelas XI di MA Rahmat Sa'id Bongkot Peterongan.

\section{B. Reciprocal Teaching, Bamboo Dancing, dan Hasil Belajar}

\section{Pengertian Model Reciprocal Teaching}

Reciprocal Teaching adalah model pembelajaran yang berupa kegiatan mengajarkan materi kepada teman. Pada model pembelajaran ini peserta didik berperan sebagai "guru" untuk menyampaikan materi kepada teman-temannya. Sementara itu, guru lebih berperan 


\section{Roikhatul Machbubah, Khoirun Nisa'}

sebagai model yang menjadi fasilitator dan pembimbing yang melakukan scaffolding. Scaffolding adalah bimbingan yang diberikan oleh orang yang lebih tahu kepada orang yang kurang tahu atau belum tahu.

Reciprocal Teaching mengandung 4 strategi :

\section{a. Question Generating}

Dalam starategi ini peserta didik diberi kesempatan untuk membuat pertanyaan terkait materi yang sedang dibahas. Pertanyaan tersebut diharapkan dapat mengungkapkan penguasaan konsep terhadap materi yang sedang dibahas.

b. Clarifying

Clarifying merupakan kegiatan penting saat pembelajaran. Terutama bagi siswa yang mempunyai kesulitan dalam memahami suatu materi. Siswa dapat bertanya kepada guru tentang konsep yang dirasa masih sulit atau belum terpecahkan bersama kelompoknya. Selain itu, guru dapat mengklarifikasi konsep dengan memberikan pertanyaan kepada siswa.

c. Predicting

Ini merupakan startegi dimana siswa melakukan hipotesis atau perkiraan menganai konsep apa yang akan didiskusikan selanjutnya.

\section{d. Summarizing}

Strategi ini terdapat kesempatan bagi siswa untuk mengidentifikasikan informasiinformasi yang terkandung dalam materi.

Langkah-langkah pembelajaran Reciprocal Teaching

1. Mengelompokkan peserta didikdan diskusi kelompok

2. Membuat pertanyaan (Question Generating) 


\section{Perbandingan Model Pembelajaran Reciprocal Teaching Dengan Bamboo Dancing}

Berbasis Cooperatif Learning

3. Menyajikan hasil kerja kelompok

4. Mengklarifikaiskan permasalahn (Clarifying)

5. Memberikan soal latihan yang memuat soal pengembangan

6. Menyimpulkan materi yang dipelajari. ${ }^{3}$

Kekurangan dari model Reciprocal Teaching adalah :

1. Adanya kekurang-sungguhan para siswa yang berperan sebagai guru menyebabkan tujuan tak tercapai.

2. Pendengar sering menertawakan tingkah laku siswa yang menjadi guru sehingga merusak suasana.

3. Butuh waktu yang lama.

4. Sangat sulit diterapkan jika pengetahuan siswa tentang materi belum faham.

5. Tidak mungkin seluruh siswa akan mendapat giliran menjadi "guru siswa"

Kelebihan dari model Reciprocal Teaching adalah :

1. Mengembangkan kreativitas siswa

2. Memupuk kerja sama antarsiswa

3. Siswa belajar dengan mengerti

4. Siswa belajar dengan mandiri

5. Memupuk keberanian berpendapat dan berbicara kedepan kelas.

Jadi Reciprocal Teaching adalah suatu model pembelajarn dimana peserta didik dirikan kesempatan untuk mempelajari materi terlebih dahulu. Kemudian siswa menjelaskan kembali materi yang dipelajari kepada siswa lain. Guru hanya bertugas sebagai falitator dan seorang pembimbing dalam proses belajar mengajar. Yakni dengan meluruskan atau memberi

\footnotetext{
${ }^{3}$ Aris Shoimin, 68ModelPembelajaran Inovatif dalam Kurikulum 2013 (Yogyakarta: Ar-Ruzz Media, 2017), 153.
} 


\section{Roikhatul Machbubah, Khoirun Nisa'}

penjelasan mengenai materi yang sulit dipecahkan secar mandiri oleh siswa.

\section{Pengertian Model Pembelajaran Bamboo Dancing (Tari Bambu)}

Model pembelajaran Bamboo Dancing bertujuan agar peserta didik saling berbagi informasi bersama-sama dengan pasangan yang berbeda dalam waktu singkat secara teratur.

Pembelajarn diawali dengan topik. Guru bisa menuliskan topik tersebut dipapan tulis atau mengadakan tanya jawab tentang materi yang diajarkan. Kegiatan saling tukar pikiran ini dimaksudkan agar mengaktifkan struktur kognitif yang dimiliki peserta didik agar lebih siap menghadapi pelajaran baru.

Model pembelajaran Bamboo Dancing ini bertujuan agar peserta didik saling berbagi informasi (sharing) informasi pada saat bersamaan dengan pasangan yang berbeda dalam waktu singkat secara teratur. Meskipum bernama bamboo dancing tidak menggunakan bambu. Siswa yang berjajarlah yang di ibaratkan sebagai bambu.

Langkah-Langkah Pembelajaran Bamboo Dancing :

a. Separuh jumlah siswa dikelas berdiri berjajar.

b. Separuh kelas lainnya berjajar dan menghadap jajaran pertama.

c. Dua siswa yang berpasangan dari kedua jajarana pindah ke ujung lainnya di jajarannya. Jajaran inin kemudia bergeser. ${ }^{4}$

Kekurangan model pembelajaran Bamboo Dancing adalah :

a. Kelompok belajarnya terlalu gemuk sehingga menyulitkan proses belajar mengajar.

b. Siswa lebih banyak bermain darpada belajar.

c. Memerlukan periode waktu yang cukup panjang.

Kelebihan model pembelajaran Bamboo Dancing adalah :

${ }^{4}$ Ibid. 33 . 


\section{Perbandingan Model Pembelajaran Reciprocal Teaching Dengan Bamboo Dancing \\ Berbasis Cooperatif Learning}

a. Siswa dapat bertukar pengalaman dan pengetahuan dengan sesamanya dalam proses pembelajaran.

b. Meningkatkan kecerdasan sosial dalam hal kerja sama di antara siswa.

c. Meningkatkan toleransi antara siswa.

\section{Pengertian Hasil Belajar}

Belajar adalah suatu proses dalam pengertian yang luas tingkah laku ditimbulkan atau dirubah melalui praktik atau latihan, jadi hasil belajar ini sendiri merupakanakumulasi dari suatu kegiatan dengan jalan latihan atau praktek yang dilakukan oleh peserta didik.Hasil belajar adalah kemampuan- kemampuan yang dimiliki siswa setelah ia menerima pengalaman belajar. Sedangkan hasil belajar dapat ditunjukkan dalam berbagai bentuk seperti perubahan pengetahuannya, pemahamannya, sikap dan tingkah lakunya, kecakapan dan kemampuaanya, daya reaksinya dan daya penerimanya. ${ }^{5}$

Dari pernyataan di atas, dapat disimpulkan bahwasanya hasil belajar adalah perubahan yang dicirikan sebagai suatu hasil belajar yang baik dan menciptakan pengetahuan yang semakin meningkat dari semula. Perubahan yang terjadi meliputi tiga aspek, yaitu kognitif, afektif dan psikomotorik. Hasil yang akan dicapai dari suatu kegiatan dan usaha menerima, menanggapi atau menganalisa mata pelajaran tertentu yang diketahui melalui evaluasi berupa tes atau ujian.

\section{a. Klasifikasi Hasil Belajar Siswa}

Domain hasil belajar adalah perilaku-perilaku kejiwaan yang akan diubah dalam proeses pendidikan. Perilaku kejiwaan itu dibagi dalam tiga domain yaitu kognitif, afektif dan piskomotorik. Ketiga ranah tersebut menjadi objek penilaian hasil belajar. Di antara 


\section{Roikhatul Machbubah, Khoirun Nisa'}

ketiga ranah itu adalah ranah kognitiflah yang paling banyak dinilai oleh para guru di sekolah karena berkaitan dengan kemampuan peserta didik dalam menguasai isi bahan pengajaran.

Berdasarkan teori Taksonomi Bloom hasil belajar dicapai melalui tiga kategori ranah antara lain: kognitif, afektif dan psikomotorik. Perinciannya adalah sebagaiberikut:

a) Domain kognitif atau ranah kognitif

Ranah kognitif adalah ranah yang mencakup kegiatan mental (otak) atau ranah proses berpikir. Kemampuan kognitif ini mempunyai enam tingkatan yaitu pengetahuan (knowledge), pemahaman (comprehension), penerapan (application), analisis (analysis), sintesis(synthesis) dan penilaian(evaluation).

b) Domain Afektif atau ranah afektif

Ranah afektif merupakan ranah yang berkaitan dengan sikap dan nilai. Dan ranah ini memiliki lima tingkatan, yaitu menerima (receiving), menanggapi(responding), menilai (valuing), mengatur atau mengorganisasikan (organization) dan karakterisasi dengan suatu nilai/ komplek nilai (characterization).

c) Domain psikomotorik atau ranah psikomotorik

Sedangkan psikomotorik adalah ranah yang berkaitan dengan keterampilan/ kemampuan bertindak setelah seseorang menerima pengalaman belajar tertentu.

\section{b. Cara Mendapatkan Hasil Belajar}

Untuk mengukur tingkat keberhasilan belajar dapat dilakukan melalui tes hasil belajar. Berdasarkan tujuan dan ruang lingkupnya, tes hasil belajar dapat digolongkan ke dalam jenis penilaian berikut: 


\section{Perbandingan Model Pembelajaran Reciprocal Teaching Dengan Bamboo Dancing}

Berbasis Cooperatif Learning

\section{a) Tes Formatif}

Tes formatif digunakan untuk mengetahui sejauh mana kemampuan siswa setelah mengikuti proses belajar mengajar. Tes formatif diujikan setelah siswa menyelesaikan materi-materi tertentu. Tesformatif dalam praktik pembelajaran dikenal sebagai ulangan harian

\section{b) Tes Sumatif}

Tes sumatif sebagai tes yang digunakan untuk mengetahui penguasaan siswa atas semua jumlah materi yang disampaikan dalam satuan kurun waktu tertentu seperti catur wulan atau semester. Dalam praktik pengajaran tes sumatif dikenal sebagai ujian akhir semester atau catur wulan tergantung satuan waktu yang digunakanuntuk menyelesaikan pelajaran.

c) Tes Diagnostik

Tes hasil belajar yang digunakan sebagai dasar untuk melakukan evaluasi diagnostik adalah tes diagnostik. Dalam evaluasi diagnostik, tes hasil belajar digunakan untuk mengidentifikasi siswa-siswa yang mengalami masalah dan menelusuri jenis masalah yang dihadapi.

d) Tes Penempatan

Tes penempatan adalah tes hasil belajar yang dilakukan untuk menempatkan siswa dalam kelompok yang sesuai dengan kemampuan ataupun bakat minatnya. ${ }^{6}$

\section{c. Faktor-Faktor yang Mempengaruhi Hasil Belajar}

Faktor-faktor yang mempengaruhi hasil belajar banyak jenisnya, tetapi dapat

${ }^{6}$ Ibid. 22 


\section{Roikhatul Machbubah, Khoirun Nisa'}

digolongkan menjadi dua, yaitu faktor internal dan faktor eksternal. Faktor internal adalah faktor yang ada dalam diri individu, sedangkan faktor eksternal adalah yang ada di luar individu. Berikut adalah penjabarannya :

1) Faktor Internal

Ada tiga faktor internal yaitu faktor jasmaniah, faktor psikologis dan faktor kelelahan/letih.

2) Faktor Eksternal

a) Faktor keluarga meliputi cara orang tua mendidik, suasana rumah dan latar belakang kebudayaan.

b) Faktor sekolah meliputi metode mengajar, kurikulum, relasi guru siswa, relasi siswa dengan siswa dan metode belajar.

c) Faktor masyarakat. ${ }^{7}$ Masyarakat merupakan faktor ekstern yang juga berpengaruh terhadap belajar siswa. Pengaruh itu terjadi karena 'keberadaan siswa dalam masyarakat. Adapun faktor tersebut meliputi kegiatan siswa dalam masyarakat, massa media, teman bergaul dan bentuk kehidupan masyarakat, yang semuanya mempengaruhi belajar.

Faktor-faktor tersebut saling berinteraksi secara langsung atau tidak langsung dalam mempengaruhi hasil belajar yang dicapai seseorang. Faktor-faktor seperti yang dikemukaan diatas mempengaruhi suasana belajar siswa, sehingga konsentrasi dalam memperhatikan materi dapat terganggu yang menyebabkan tidak tercapainya tujuan pembelajaran seperti yang diharapkan.

Tinggi dan rendahnya hasil belajar yang diperoleh siswa berkaitan dengan faktor yang

${ }^{7}$ Ibid., 23 


\section{Perbandingan Model Pembelajaran Reciprocal Teaching Dengan Bamboo Dancing \\ Berbasis Cooperatif Learning}

mempengaruhinya. Setelah mengetahui berbagai faktor-faktor yang mempengaruhi hasil belajar, diharapkan seorang guru mampu melakukan inovasi dan kreativitas yang menyenangkan dalam proses pembelajaran supaya terhindar dari berbagai faktor yang bisa menghambat.

\section{Perbandingan Model Pembelajaran Reciprocal Teaching dengan Bamboo Dancing}

Seperti yang sudah kita ketahui sebelumnya model pembelajaran Reciprocal Teaching adalah salah satu model pembelajaran kooperatif, dimana seorang siswa bertindak sebagai guru. Dan guru sebagai scaffolding. Scaffolding artinya guru memberikan informasi kepada orang yang kurang tahu agar menjadi lebih tahu. Model pembelajaran ini mengajarkan agar anak didik bisa mengasah biacara nya didepan publik atau siswa lainnya. Ini berguna meningkatkan rasa kepercayaan dirinya di depan umum.

Adapun model pembelajaran Bamboo Dancing adalah model pembelajaran yang terinspirasi dari bambu. Dimana siswa akan diajak maju kedepan dan berjajar mengahadap teman lain yang berjajar pula. Model pembelajaran ini bertujuan agar antar peserta didik dapat bertukar pikiran dan mengaktifkan rana kognitif yang dimiliki oleh peserta didik lainnya.

Perbedaan model pembelajaran Reciprocal Teaching dengan Bamboo Dancing terletak pada cara penyampaian proses belajar mengajar. Model Reciprocal Teaching mengutamakan gaya bahasa atau gaya bicara peserta didik dalam menyampaikan materi yang disampaikan, sedangkan model pembelajaran Bamboo Dancing mengutamakan keaktifan seorang siswa dalam mensalurkan apa yang ia dapatkan kemudian mereka saling bertukar pikiran dengan yang teman yang lain. 


\section{Roikhatul Machbubah, Khoirun Nisa'}

\section{DAFTAR PUSTAKA}

Shoimin, Aris. Model Pembelajaran Inovatif dalam Kurikulum 2013, 2017. Yogyakarta: Ar-Ruzz Media.

Muijs, Daniel \& David Reynolds, 2011. Effective Teaching: Teori dan Aplikasi. Cet. I; Yogyakarta: Pustaka Pelajar.

Undang-Undang No.20 Th. 2003 tentang Sistem Pendidikan Nasional, 2009. Jakarta : Sinar Grafika.

Slavin, Robert E. Cooperative Learning Teori, Riset dan Praktik. 2005.

Cet.XV; Bandung: Nusa Media.

Warsono, dan Hariyanto, Pembelajaran Aktif Teori dan Asesmen. 2013. Cet. II; Bandung: Remaja Rosdakarya. 